UDC 539.3

M. Vabishchevich, $\mathrm{PhD}$,

R. Stryhun

Kyiv National University of Construction Architecture, 31 Povitroflotsky Ave., Kyiv, Ukraine, 03037; e-mail: r.l.strigun@gmail.com

\title{
SIMULATION OF THE PROCESS OF SHRINKAGE
}

\author{
OF THE CONICAL WORKPIECE OF THE STEAM TURBINE \\ ROTOR BY THE SEMI ANALYTICAL FINITE \\ ELEMENT METHOD
}

\begin{abstract}
М.О. Вабіщевич, Р.Л. Стригун. Моделювання процесу усадки конічної заготовки ротора парової турбіни напіваналітичним методом скінченних елементів. Дослідження напружено-деформованого стану (НДС) тіл обертання $\epsilon$ важливою задачею як з теоретичної, так і з практичної точки зору, враховуючи їх широке застосування в різних галузях техніки. Метою наукового дослідження $є$ моделювання та вивчення процесу формозміни конічної заготовки ротора парової турбіни під дією динамічного навантаження з урахуванням умов контактної взаємодії з інструментом, фізичної та геометричної нелінійності за допомогою напіваналітичного методу скінченних елементів (НMCЕ). Для опису динамічного деформування тіл обертання використані вихідні співвідношення просторової задачі теорії пружності в криволінійних системах координат. За межею пружності зв’язок між напруженнями і деформаціями прийнятий у відповідності з рівняннями теорії пластичної течії при умові текучості Мізеса для ізотропно-зміцнюваного матеріалу. Опис напружено-деформованого стану базується на використанні початкової, перехідної і остаточної конфігурацій та розглядається в рамках моментної схеми в термінах фізичних компонент тензорів напружень та деформацій. Для моделювання взаємодії системи контактуючих тіл використано спеціальний контактний скінченний елемент, що забезпечує взаємну непроникність окремих елементів конструкції. Найбільш ефективним підходом до розв'язання поставленої задачі є використання напіваналітичного варіанта метода скінченних елементів, що займає особливе місце серед математичних аналітичних i чисельних методів. Апроксимація базується на розкладі невідомих i заданих функцій скінченноелементної моделі вздовж направляючої по деякій системі безперервних гладких функцій та скінченноелементної дискретизації в області поперечного перерізу скінченного елемента (CЕ). Розподілення переміщень в межах поперечного перетину $\mathrm{CE}$ описується білінійним законом. В роботі розглянуто еволюційні процеси, що виникають під час виготовлення ротора парової турбіни. А саме усадки конічної заготовки в умовах високої температури під дією динамічного навантаження. Проведені дослідження з варіюванням кута нахилу твірної та коефіцієнта тертя на поверхні контакту з інструментом, що мають визначальний вплив на напружено-деформований стан, та, як результат на зміну форми меридіонального перерізу готової деталі в процесі усадки. Запропонований підхід реалізований у вигляді пакету прикладних програм, що орієнтований на сучасні ПЕОМ.

Ключові слова: напіваналітичний метод скінченних елементів, тіла обертання, пластичні деформації, геометрична нелінійність, динамічні процеси

$M$. Vabishchevich, R. Stryhun. Simulation of the process of shrinkage of the conical workpiece of the steam turbine rotor by the semi analytical finite element method. The study of stress-strain state (SSS) is an important task from both a theoretical and a practical point of view, encompassing their widespread use in various fields of technology. The purpose of scientific research is to simulate and study the process of shaping of the conical workpiece of the rotor of a steam turbine under dynamic load, taking into account the conditions of contact interaction with the instrument, physical and geometric nonlinearity using the semi-analytical finite elements method (SAFEM). To describe the dynamic deformation of the body of the survey, the initial relations of the spatial problems of the theory of elasticity in the curvilinear coordinate systems are used. By the limit of elasticity, the relationship between stresses and deformations taken in accordance with the equation of the theory of plastic flow under the condition of the current time for the isotopically varying material. The description of the stress-strain state based on the use of initial, transient and final configurations and considered within the framework of the current scheme of physical components. To simulate interacting contact systems, use a special contact element that provides mutual opacity of the individual elements of the design. The most effective approach to solving the problem is to use an administrative variant of methodological approaches that occupy a place among mathematical and social methods. The approximation based on the decomposition of unknown and given functions of a finite-element model along a system of continuous smooth functions and finite-element sampling in the region of the cross section of a finite element. The distribution shifted within the transverse section of the CE described by the bilinear law. The paper considers evolutionary processes that arise during the manufacture of a steam turbine rotor. Namely shrinkage of the conical workpiece at high temperature under the action of dynamic load. A study conducted with variation of the slope angle and friction coefficient on the surface of the contact with the tool having an effect on the tensile and deformation state, as well as the result of changing the form of the meridional section of the finished part during its shrinkage. The offered approach is relevant in the presented software packages oriented on the modern PC.

Keywords: semi analytical finite element method, rotational body, plastic deformations, geometric nonlinearity, dynamic processes
\end{abstract}

DOI: 10.15276/opu.1.57.2019.05

(c) 2019 The Authors. This is an open access article under the CC BY license (http://creativecommons.org/licenses/by/4.0/). 
Introduction. One of the most important stages in the manufacture of steam turbine rotors is the precipitate of blanks. The study of stresses and deformations in the volume of a deformed body is a task from which successful solution depends on the prediction of the formation of defects, the refinement of the strength and kinematic characteristics of the process and its optimization. The purpose of this study is to analyze the effect of changing the geometric dimensions of the object and the level of roughness of the contact surfaces of the tool and workpiece on the nature of the stress-strain state (SSS) of the body.

The solution of the above class of tasks represents significant mathematical difficulties and is possible only within the framework of numerical methods. The most universal numerical method used in scientific research, especially for the calculation of complex objects, is the finite element method (FEM). It gives freedom in choosing the size of finite elements, placing them, and in problems with complex geometry, it allows you to combine the form. Nowadays alternative methods for determining the stress-strain state of objects have become widespread. Substantial expansion of the possibilities of the FEM for the class of objects considered in the work, due to the consideration of their features, allows the semi-analytic method of finite elements (SAFEM). Its essence is the decomposition of unknown and given functions along the direction of a continuous system of smooth functions and finite element sampling in the region of a cross section.

Analysis of recent publications and the problem statement. The results of this work are a logical continuation of scientific work in the direction of expanding the spectrum of problems that are considered on the basis of the semi-analytic method of finite elements. The SAFEM has been proposed in works by Zenkevich O. [1] and Wilson E. [2] as an effective method for solving spatial static problems of linear and nonlinear systems. The apparent effectiveness of this approach gave a further impetus to its development into other classes of problems [3]. Examples of objects can be tower towers, water towers, chimneys, reservoirs of various purposes, protective shells of nuclear reactors, various nodes and parts of power and transport engineering, covering, overlappings, foundations of industrial and civil buildings and structures, tunnels, etc. The large prevalence of these forms in the construction and machine-building industries of the national economy on the one hand, and the possibility of a significant simplification of the decoupling ratios due to their geometric peculiarities on the other, attracts more and more attention of researchers. Thus, the realizations of the semi-analytic finite element method for the analysis of the processes of destruction of primeval bodies [4], dynamic deformation at different loading intensities [5], which are considered for essentially heterogeneous constructions, including initial geometric imperfections and cutouts that violate axial symmetry, are known. In addition, the circular unclosed and prismatic bodies [4 -6] of the complicated phoemy and cross-sectional structures occur in the area of application of SAFEM. At the same time, within the framework of the SAFEM, there are not sufficiently highlighted the issue of creating effective approaches for constructing discrete dynamic models of spatial bodies of rotation of non-canonical forms for processes accompanied by a significant change in the initial form and significant plastic deformations.

The purpose and objectives of the study. The purpose of this work is to develop an effective approach to the study of transient processes of dynamic deformation of inhomogeneous spatial bodies of rotation under the action of a variable in time and space of impulse loading taking into account the plastic properties of the material, time-varying conditions of contact interaction and significant deformations, based on the semi-analytic finite element method. Obtaining on this basis new results of important application tasks.

Initial relations of the semi-analytic method of finite elements for geometrically and physically nonlinear dynamics problems. Approximations of the presented class of structures in the proposed software complex are based on a ring quadrilateral four-node finite element, taking into account the variability of the components of the metric tensor in the plane of the element and the explicit integration in the averaging of the characteristics of materials in its center [5] (Fig. 1).

Here $d^{i j k l}\left(x^{3}\right)$ is the tensor of the physical-mechanical characteristics of the material, $\rho\left(x^{3}\right)-$ the density, $\sigma^{i j}\left(x^{3}\right)$ - the components of the stress tensor, which are calculated at points along the circum- 
ferential coordinate $x^{3}$. The indices $S_{1}$ and $S_{2}$ determine the position of the node relative to the center of the cross-section of the element and acquire the values \pm 1 .

The description of geometrical and mechanical characteristics, initial and boundary kinematic conditions is carried out in the orthogonal circular cylindrical system $Z^{i^{\prime}}$ [7].

The local coordinate system $x^{i}$ is associated with the material particles of the body and, when the body is loaded, deforms with it. In this case, the change in the metric characteristics of the coordinate system at each point is a measure of deformation, which allows uniquely determining the geometry of the deformed body based on its initial state. There are three body configurations: a reference initial, a reference variable and an actual one. The components of the metric tensor of these states denote respectively $\bar{g}_{i j}$, $g_{i j}, G_{i j}$.

Using the variable reference configuration, you can present the components of the deformation tensor $\varepsilon^{i j}$ in the actual configuration as a sum:

$$
\varepsilon^{i j}=\bar{\varepsilon}^{i j}+\varepsilon^{i j},
$$

where $\bar{\varepsilon}^{i j}=\frac{\bar{g}^{i j}-g^{i j}}{2}$ - deformation of

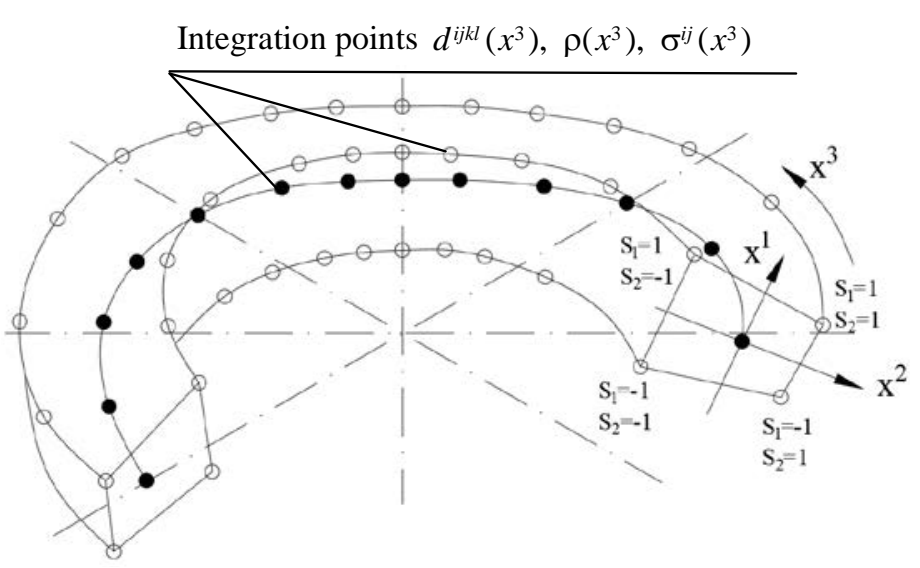

Fig. 1. Closed ring finite element

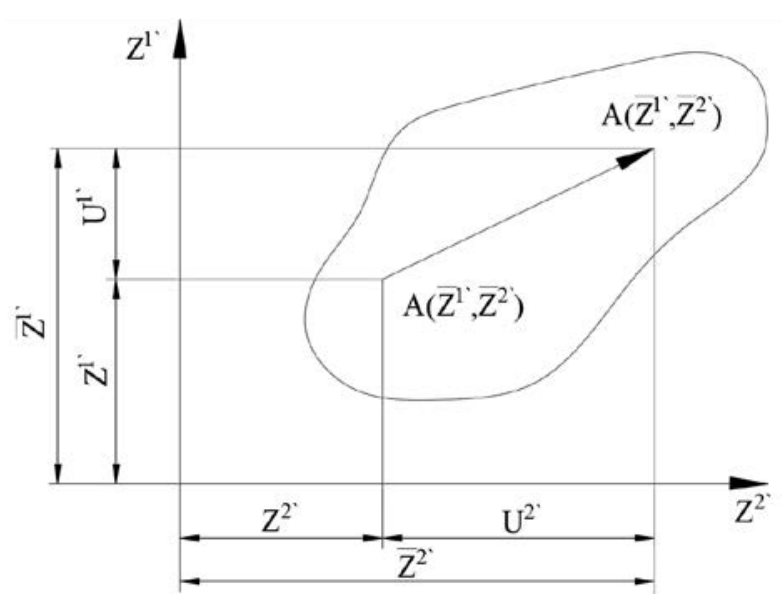

Fig. 2. The variable counting and actual configuration

bodies in the reference configuration variable in relation to the initial state;

$\varepsilon^{i j}=\frac{g^{i j}-G^{i j}}{2}-$ deformation of the body in the actual configuration in relation to the reference variable.

Fig. 2 shows the position of some point $A$, which belongs to the meridional cross section of the body of the variable reference and actual configuration. The new position of the point $A$ in the system $Z^{i^{\prime}}$ is determined by the coordinates:

$$
Z^{\alpha^{\prime}}=\bar{Z}^{\alpha^{\prime}}+U^{\alpha^{\prime}}
$$

By differentiating the coordinates of the local system $x^{i}$, we obtain the components of the transformation tensor:

$$
Z_{, \beta}^{\alpha^{\prime}}=\bar{Z}_{, \beta}^{\alpha^{\prime}}+U_{, \beta}^{\alpha^{\prime}}
$$

Returning to (1), we have:

$$
\Delta \varepsilon^{i j}=\frac{\bar{g}^{i j}-G^{i j}}{2}=\frac{\bar{g}^{i j}-\bar{g}^{i j}+G^{i m} \Delta G_{m n} G^{m \gamma}}{2} \approx \frac{\bar{g}^{i m} \bar{g}^{j n} \Delta G_{m n}}{2} .
$$

For heterogeneous circular bodies of rotation due to the convergence of $x^{3}$ and $Z^{3^{\prime}}$ and their orthogonality to the plane of the cross section in a cylindrical coordinate system $\left(0 \leq x^{3} \leq 2 \pi\right)$ : 


$$
z_{, \alpha}^{3^{\prime}}=z_{, 3}^{\alpha^{\prime}}=0, z_{, 3}^{3^{\prime}}=1 .
$$

The covariant components of the deformation of the actual configuration relative to the reference variable take the following form in an orthogonal cylindrical coordinate system:

$$
\begin{gathered}
\varepsilon_{\alpha \beta}=\frac{z_{, \alpha}^{\gamma^{\prime}} u_{\gamma^{\prime}, \beta}+z_{, \beta}^{\gamma^{\prime}} u_{\gamma^{\prime}, \alpha}}{2}, \\
\varepsilon_{\alpha 3}=\frac{1}{2}\left(u_{3^{\prime}, \alpha}+z_{, \alpha}^{\gamma^{\prime}} u_{\gamma^{\prime}, 3}-\frac{2 z_{, \alpha}^{2^{\prime}} u_{3^{\prime}}}{Z^{2^{\prime}}}\right), \\
\varepsilon_{33}=u_{3^{\prime}, 3}+Z^{2^{\prime}} u_{2^{\prime}} .
\end{gathered}
$$

According to the accepted hypotheses, the geometric equations (4) are valid for small deformations $\Delta \varepsilon_{i j}$ and large displacements, and (6) only with small deformations and small displacements.

Full tensions can be represented as:

$$
\sigma^{i j}=\bar{\sigma}^{i j}+\Delta \sigma^{i j},
$$

where $\bar{\sigma}^{i j}$ - stresses achieved during deformation of the body in the reference configuration;

$\Delta \sigma^{i j}$ - increase of stresses caused by deformations of the body during deformation from the variable of the reference to the actual configuration.

It is assumed that in the process of loading in the body volume there are elastic $\varepsilon_{i j}^{e}$ and instant plastic $\varepsilon_{i j}^{p}$ deformations. By the limit of elasticity, the relationship between stresses and deformations is taken in accordance with the equations of the theory of plastic flow under the condition of Mises fluidity for an isotropically reinforcing material. [7].

To simulate the interaction of bodies, a thin contact layer is introduced, within which the stressstrain state is described in the additional coordinate system $y^{i^{\prime \prime}}$, which is associated with the configuration of the surfaces of bodies [5].

At each time $t$ the conditions of non-penetration, friction on the basis of the Coulomb's law and the absence of tensile stresses normal to the contact surface are provided:

$$
\sigma_{t}^{n^{\prime \prime}\left(n^{\prime \prime}\right)} \leq 0, \tau_{t} \leq f_{f r} \sigma_{t}^{n^{\prime \prime}\left(n^{\prime \prime}\right)}
$$

where $f_{f r}$ - friction coefficient;

$n^{\prime \prime}$ - normal to the contact surface.

It is assumed that for the contact layer, the density of the material and the Poisson coefficient are zero:

$$
\rho_{c}=0, \quad \nu_{c}=0 .
$$

The formulation (9) provides the masslessness of the boundary and the instantaneous transfer of effort from one body to another under dynamic load.

The motion of an inhomogeneous isotropic body, the volume $V$ bounded by the surface $S$, is described by the equation that follows from the principle of D'Almerbert, whose component form in the curvilinear coordinate system takes the form:

$$
\frac{1}{\sqrt{g}} \frac{\partial}{\partial x^{i}}\left(\sqrt{g} z_{, k}^{j^{\prime}} \sigma^{k i}\right)+f^{j^{\prime}}=\rho \ddot{j^{j^{\prime}}} .
$$

The uniqueness of the solution (10) is ensured by the introduction of the corresponding initial and boundary conditions. The initial conditions are the known distribution of displacements and speeds in the body at a certain fixed time point $t_{0}$, which is taken at the start of the time coordinate:

$$
u\left(Z^{i^{\prime}}, t_{0}\right)=u_{0}\left(Z^{i^{\prime}}\right), \dot{u}\left(Z^{i^{\prime}}, t_{0}\right)=\dot{u}_{0}\left(Z^{i^{\prime}}\right), Z^{i^{\prime}} \in V .
$$

It is assumed that the kinematic boundary conditions are given on a part of the surface $S_{u}$ :

$$
u\left(Z^{i^{\prime}}, t\right)=\tilde{u}\left(Z^{i^{\prime}}, t\right), Z^{i^{\prime}} \in S_{u},
$$


and on a surface $S_{p}$ with a normal $\vec{n}=n_{j} e^{j}$ - an arbitrarily oriented space and time load system:

$$
Z_{, i}^{k^{\prime}} \sigma^{i j} n_{j}=\tilde{p}\left(Z^{k^{\prime}}, t\right), Z^{k^{\prime}} \in S_{p} .
$$

Mathematically, the model of such processes is realized in the form of linear or nonlinear differential equations of the second order, for solution of which direct methods of direct integration of equations of motion in time coordinate are recommended. This paper uses the most accurate of them - a method N'yumarka [8], which is adapted to the amplitude subsystems SAFEM [5].

Investigation of optimal parameters of the shrinkage process of rotor workpiece steam turbine.

Consider the workpiece (Fig. 3), in which the angle of the creature's slope $\alpha$ varies from $3^{\circ}$ to $7^{\circ}$. Height $H_{0}=280 \mathrm{~cm}$ and average radius $R_{a v}^{0}=72.5 \mathrm{~cm}$. The sediment $\Delta$ is carried out to a degree of deformation $H / H_{0}=0.53$ corresponding to the height $H=150 \mathrm{~cm}$. The initial temperature $T=1200{ }^{\circ} \mathrm{C}$, the material is $25 \mathrm{XH} 3 \mathrm{MФA}$ steel.

To improve the approximation of the object, it was decided to select a relatively thin layer of finite elements along the outer contour of the meridional section of the workpiece, with a thickness $H / 20$. Investigation of the convergence of shrinkage, radial displacement, axial and circumferential stresses was carried out with an increase in the number of finite elements only in the inner region of the cross-section.

Fig. 4 shows changes in the shape of the meridional section in the process of shrinkage with different angles of slope of the creature. A characteristic feature of the initial stage of deformation $H / H_{0}=1 \ldots 0.86$ is a predominant increase in the radius of the cone in the region of the upper base.

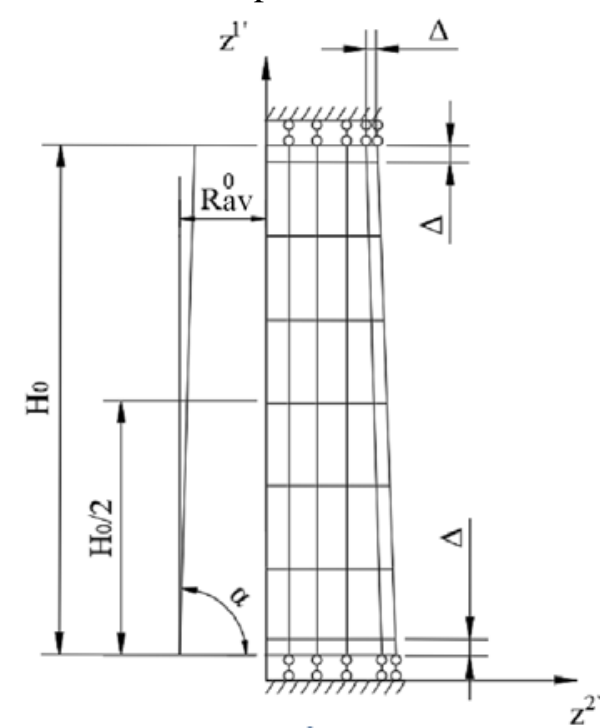

Fig. 3. Finite element model of rotor workpiece steam turbine

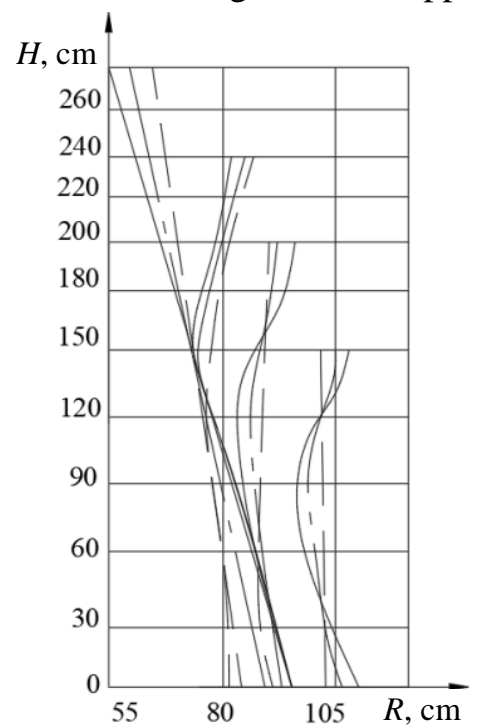

Fig. 4. Change the shape of the meridional section in the process of shrinkage. The dashed line corresponds to the process of deforming the workpiece with an initial angle of inclination of $3^{\circ}$, dash dotted and solid $5^{\circ}$ and $7^{\circ}$ respectively

At the next stage $H / H_{0}=0.86 \ldots . .0 .71$ there is a gradual development of radial deformations throughout the meridional section height, taking into account the increase in the angle of inclination $\alpha$, which is proportional to which it also increases.

In the interval $H / H_{0}=0.71 \ldots 0.53$ there is a relatively even distribution of displacements in the axial direction. The final form of forgings at a magnitude of $3^{\circ}$ is closer to the cylindrical one, since the maximum difference of the lateral coordinates does not exceed $2 \%$, however, with an angle of up to $5^{\circ}$, it is $9.5 \%$ and $7 \ldots 15 \%$ respectively. 
The slope of the creature significantly affects the stress-strain state of the workpiece. Fig. 5 shows diagrams of circumferential stresses, built on the height of the workpiece in the center of the boundary layer of finite elements at the magnitude of shrinkage $H / H_{0}=0.53$. Analyzing these data, one can conclude that even a slight change in the angle of inclination of the craft production, namely, from 3 to 7 degrees, has a significant effect on the deformation of the object and greatly increases the size of the circumferential tensile stresses.

The contact friction between the tool and the workpiece also significantly influences the distribution of the stress-strain state in the body of the object in the process of hot shrinkage. The study of the process was carried out taking into account the

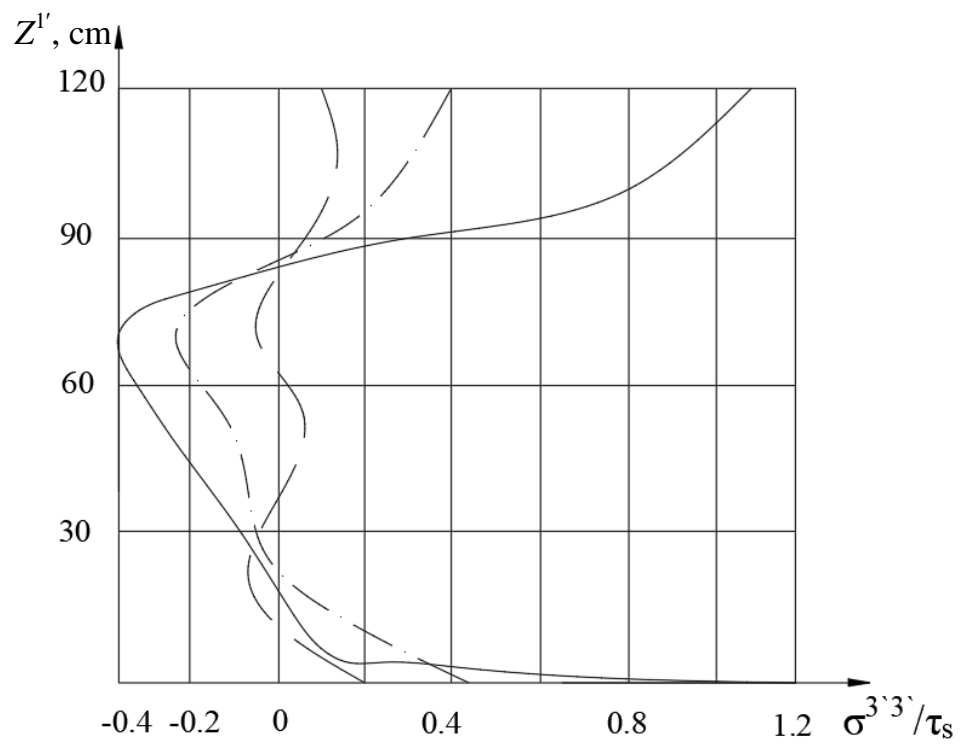

Fig. 5. Diagrams of relative circumferential stresses to the material yield strength. The dashed line shows the diagrams of the workpiece with the initial angle of the slope of the product $\alpha=3^{\circ}$, the dot with the dotted $-5^{\circ}$ and the solid- $7^{\circ}$ respectively friction $f_{m p}=0.05$ and $f_{m p}=0$. The second case corresponds to absolute slip.

Fig. 6 shows the diagrams of the radial displacements of the side surface of the workpieces $U$ (at $H / H_{0}=0.53$ ) relative to its initial height, indicating the appearance of the barrel formation process $f_{m p}=0.05$ in the central part of the cylinder and accompanied by the appearance of tensile stresses $\sigma^{3^{\prime} 3^{\prime}}$ in this zone, as shown in Fig. 7.

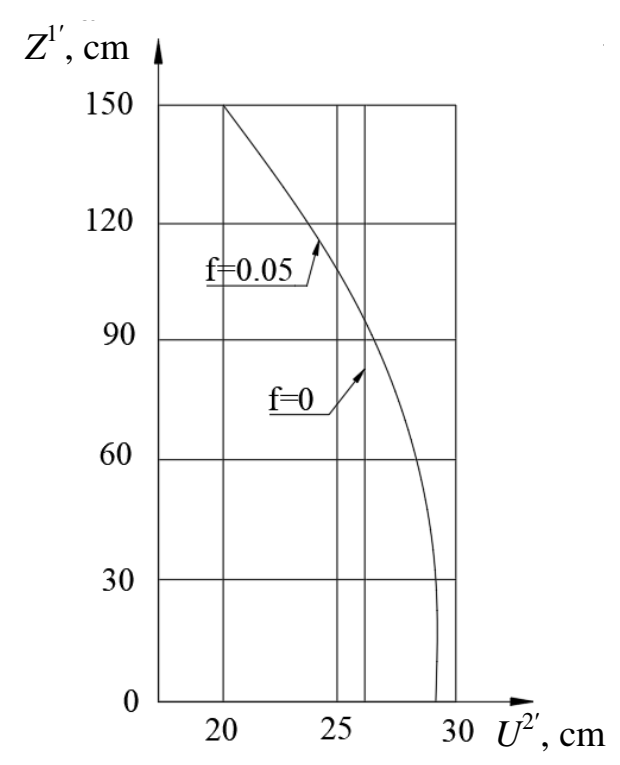

Fig. 6. Sections of radial displacements of the lateral surface of the workpiece

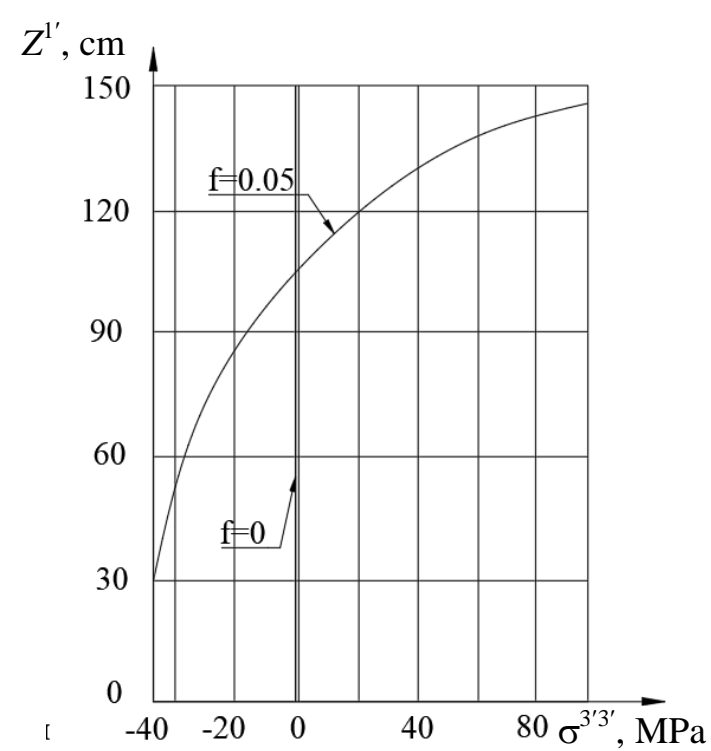

Fig. 7. Diagrams tensile stresses

Conclusions. Thus, on the basis of the semi-analytic variant of the finite element method, a new approach is proposed for studying the dynamic geometric and physically nonlinear deformation of the 
spatial system of rotational bodies, taking into account the contact interaction of their individual parts. In the framework of the proposed methodology, a demonstration of the approach possibilities was carried out on the example of the analysis of the stress-strain state of the conical billet of the rotor of the steam turbine during the precipitation process. Numerous studies have shown a significant effect of the slope of the craft's workpiece and the conditions of friction on the verge of its contact with the tool on the stress-strain state of the parts, namely, the uneven distribution of stresses in the plane of the radial cross-section, the change in the zone of tensile stresses and their quantities.

\section{Література}

1. Зенкевич, О. Метод конечных элементов в технике. Москва: Мир, 1975. 539 с.

2. Wilson E.L. Structural Analysis of Axisymmetric Solids. AIAA J. 1965. Vol. 3, No 12. P. 2269-2274.

3. Zienkiewicz O.C., Taylor R.L. Semiianalytical finite element processes - use of orthogonal functions and 'finite strip' methods. The Finite Element Method for Solid and Structural Mechanics, 6th ed.; Elsevier Butterworth-Heinemann : Oxford, UK. 2005. P. 498-516.

4. Баженов В.А., Гуляр О.І., Пискунов С.О., Сахаров О.С. Напіваналітичний метод скінчених елементів в задачах руйнування простових тіл. Київ : КНУБА, 2005. 298 с.

5. Баженов В.А., Гуляр О.І., Сахаров О.С., Солодей I.I. Напіваналітичний метод скінченних елементів в задачах динаміки просторових тіл. Київ : КНУБА, 2012. 248 с.

6. Liu P., Xing Q., Wang D., Oeser M. Application of dynamic analysis in semi-analytical finite element method. Materials. 2017. No. 10(9), 1010. DOI: 10.3390/ma10091010.

7. Блох В.И. Теория упругости. Харьков : Изд-во Харьк. ун-та, 1964. 483 с.

8. Newmark N.M. A method of computation for structural dynamics. ASCE J. Eng. Mech. Div. 1959. Vol. 85, Issue 3. p. 67-94.

\section{References}

1. Zienkiewicz, O. (1975). The method of finite elements in the technique. Moscow: Mir.

2. Wilson, E.L. (1965). Structural Analysis of Axisymmetric Solids. AIAA J., 3, 12, $2269-2274$.

3. Zienkiewicz, O.C., \& Taylor, R.L. (2005). Semiianalytical finite element processes - use of orthogonal functions and 'finite strip' methods. The Finite Element Method for Solid and Structural Mechanics, 6th ed. Elsevier Butterworth-Heinemann, Oxford: UK; 498-516.

4. Bazhenov, V.A., Gulyar, O.I., Piskunov, S.O., Sakharov, O.S. (2005). The semi-analytical finite element method in tasks of destruction of spatial bodies. Kyiv: KNUCA.

5. Bazhenov, V.A., Hulyar, O.I., Sakharov, O.S., \& Solodey, I.I. (2012). The semi-analytical finite element method in tasks of dynamics of spatial bodies. Kyiv: KNUCA.

6. Liu, P., Xing, Q., Wang, D., \& Oeser, M. (2017). Application of dynamic analysis in semi-analytical finite element method. Materials, 10(9), 1010. DOI: 10.3390/ma10091010.

7. Bloch, V.I. (1964). Theory of elasticity. Kharkiv: Publishing House Khark. univ.

8. Newmark, N.M. (1959). A method of computation for structural dynamics. ASCE J. Eng. Mech. Div., 85, 67-94.

Вабіщевич Максим Олегович; Vabishchevich Maxim, ORCID: https://orcid.org/0000-0002-0755-5186

Стригун Руслан Леонідович, Stryhun Ruslan, ORCID: https://orcid.org/0000-0002-1174-5310

Received May 09, 2019

Accepted May 27, 2019 